\title{
Systematic Literature Review: Delone And Mclean Model Using Vosviewer On Google Scholar Database Case Year 2010-2020
}

\author{
Dhian Nur Rahayu ${ }^{1}$, Anggi Elanda ${ }^{2}$, Lila Setiyani ${ }^{3 *}$ \\ ${ }^{1,2}$ Departement of Technical Information, STMIK Rosma, Karawang, West Java 41311, \\ Indonesia. \\ ${ }^{3}$ Department of Information System, STMIK Rosma, Karawang, West Java 41311, Indonesia. \\ ${ }^{*}$ Corresponding Author: \\ Email: lila.setiyani@dosen.rosma.ac.id
}

\begin{abstract}
.
This study aims to examine the development of the Delone and Mclean information system success model. This research was conducted to determine: (1) a map of the development of the number of publications on the Delone and Mclean model; (2) find out which scientific articles have the highest number of citations; (3) knowing the development map of scientific publications based on keywords. The data sources used in this study are scientific articles in the Google Scholar database with the keywords Delone and Mclean, with the categories article title, abstract, keywords in the 2016-2020 range. The search results show that there are 270 scientific articles that match the keywords based on the Harzing's Publish or Perish application. The results showed that the development of the Delone and Mclean model in 2010 - 2020 which was the highest in the Google Scholar database occurred in 2020 which reached 68 publications or 25\%. Meanwhile, the publications that have the highest number of citations are Nils Urbach and Benjamin Müller (2016) which were quoted 379 times. The development map of scientific publications based on the keywords delone and mclean analyzed using the VOSViewer application shows that the development map of the delone and mclean model is divided into 4 clusters. The red cluster 1 consists of 14 items, the green cluster 2 consists of 11 items, the blue cluster 3 consists of 10 items, and the yellow cluster 4 consists of 6 items.
\end{abstract}

Keywords: Bibliometric, Delone and Mclean, Google Scholar, VOSViewer

\section{INTRODUCTION}

The success of an information system can be seen from several things such as how good the quality of the system, the information provided, how the level of use, and user satisfaction and other things that show how big the effect is with the existence of the information system. One of the many models that can be used to measure the success of an information system is the model given by William H. DeLone and Ephraim R. McLean, which consists of six factors measuring the success of an information system. This theory was later developed in 2003 by adding service quality and combining individual impact and organizational impact into net benefits [1]. The DeLone and McLean model is a research model developed in measuring the success of an information system based on research conducted by DeLone and McLean (1992). In the DeLone and McLean model or better known as the D\&M IS Success, the dimensions of success that are measured are all interrelated [2]. 
The Delone and Mclean models have been tested for validity and quickly received responses from researchers because the model developed is quite simple and is considered valid enough for all types of information systems [3].The number of studies that analyze and measure the success of implementing an information system using the Delone and Mclean model, attracts researchers to analyze the bibliometric study of the development of the Delone and Mclean model. The data source used is a database on Google Scholar (www.scholar.google.com) for the period 2010-2020. Google Scholar is a search engine for scientific publications such as journal articles, proceeding articles, books, theses / theses, and so on. Google Scholar (Google Scholar) is a service that allows users to search for academic materials in the form of text in various publication formats. Launched in 2004, the Google Scholar index includes online journals from scientific publications [4][5].

Bibliometric analysis is a study of bibliographic analysis of scientific activities, which is based on the assumption that a researcher carries out his research and must communicate the results to colleagues. This will provide progress and development of knowledge if researchers carry out joint activities to examine specific research topics [6]. Bibliometric analysis has a role to evaluate the results of scientific research and map fields of science, track / trace the development of new knowledge in certain fields. Bibliometric indicators are calculated over a period of time and generally use two approaches, namely the number of publications, an indicator that measures productivity; and the number of citations, an indicator that measures the impact of the resulting articles [7][8].This research was conducted to answer the following problems: (1) Knowing the development of the number of publications on the Delone and Mclean topic in the 2010-2020 range. (2) Knowing the scientific articles that have the highest number of citations on the topic of Delone and Mclean. (3) Knowing the development map of scientific publications by the Delone and Mclean method based on keywords.

\section{METHODS}

This study uses a descriptive quantitative method with a bibliometric approach. Bibliometrics according to Winarko and Sormin (2010), is a study that applies mathematical and statistical methods to measure a change, both quantitatively and qualitatively in a set of documents and other media [9]. Bibliometric analysis is a quantitative method for analyzing bibliographic data in articles/journals. This analysis is usually used to investigate references to scientific articles cited in a journal, to map the scientific field of a journal, and to classify scientific articles according to a research field. This method can be used in the fields of sociology, humanities, communication, marketing, and other social groups.

The approach used in bibliometric analysis is the citation analysis approach to see 1 article cited by 1 other article, and the co-citation analysis approach to find 2 or more articles cited by 1 article [7]. The research data used in the research are scientific articles or journals in the 2010-2020 range which are sourced from the Google Scholar 
database (https://scholar.google.com). The search for scientific articles is carried out using the Publish or Perish application with the keywords "Delone and Mclean" with the category article title, abstract, keywords. As for the development map of the Delone and Mclean model of scientific publications in Indonesia analyzed using VOSViewer software, it can be seen in Figure 1. Through VOSViewer we can display large bibliometric maps in an easy way to interpret a relationship [10].

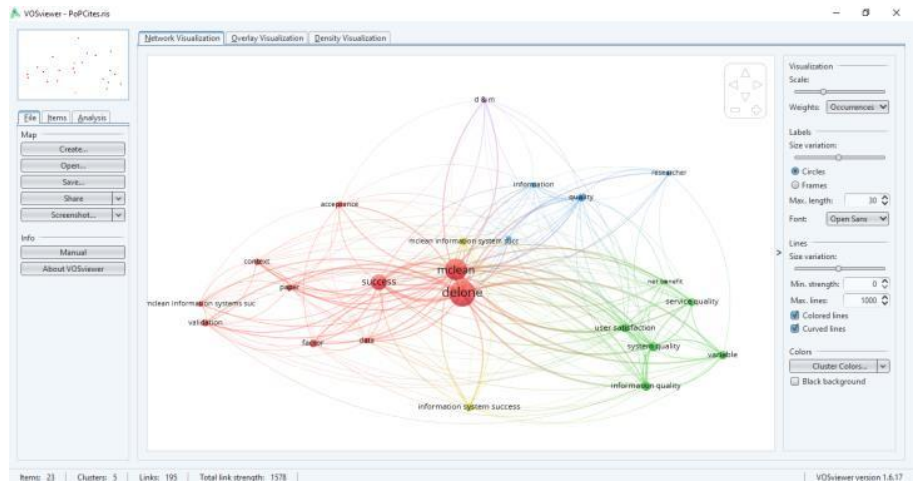

Fig 1. VOSViewer

\section{RESULT AND DISCUSSION}

\section{Publish or Perish Results}

From the results of a search using the Publish or Perish application, from the maximum number of searches used, which is 1000 articles, there are 270 publications of article titles as shown in Figure 2.

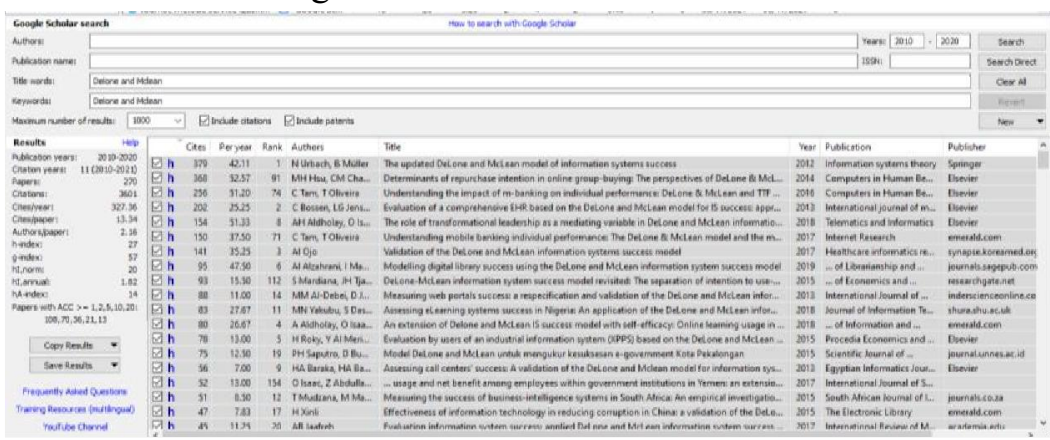

Fig 2. Publish or Perish Results

Source: Data processed, 2021

The development of the number of publications on the topic of Delone and

\section{Mclean in the period 2010-2020}

The development of publications on the topic of the Delone and Mclean method in the 2010-2020 range in the Google Scholar database has increased significantly every year. Table 1 shows that the highest number of publications regarding the Delone and Mclean method was in 2020 with 68 articles or $25 \%$ of the total data. 
Table 1. Development of the Delone and Mclean Model Publications

\begin{tabular}{|c|c|c|}
\hline Publication Year & Number of Articles & Percentage \\
\hline 2010 & 3 & $1 \%$ \\
\hline 2011 & 9 & $3 \%$ \\
\hline 2012 & 12 & $4 \%$ \\
\hline 2013 & 11 & $4 \%$ \\
\hline 2014 & 16 & $6 \%$ \\
\hline 2015 & 27 & $10 \%$ \\
\hline 2016 & 19 & $7 \%$ \\
\hline 2017 & 28 & $10 \%$ \\
\hline 2018 & 42 & $16 \%$ \\
\hline 2019 & 35 & $13 \%$ \\
\hline 2020 & 68 & $25 \%$ \\
\hline Total & $\mathbf{2 7 0}$ & $\mathbf{1 0 0 \%}$ \\
\hline
\end{tabular}

Source: Data processed, 2021

The development of the growth of publications regarding the Delone and Mclean model in the graph in Figure 3 which shows that in 2010 - 2020 the highest increase in scientific publications was in 2020. This proves that research on measuring the success of information system implementation is still attracting many researchers to date.

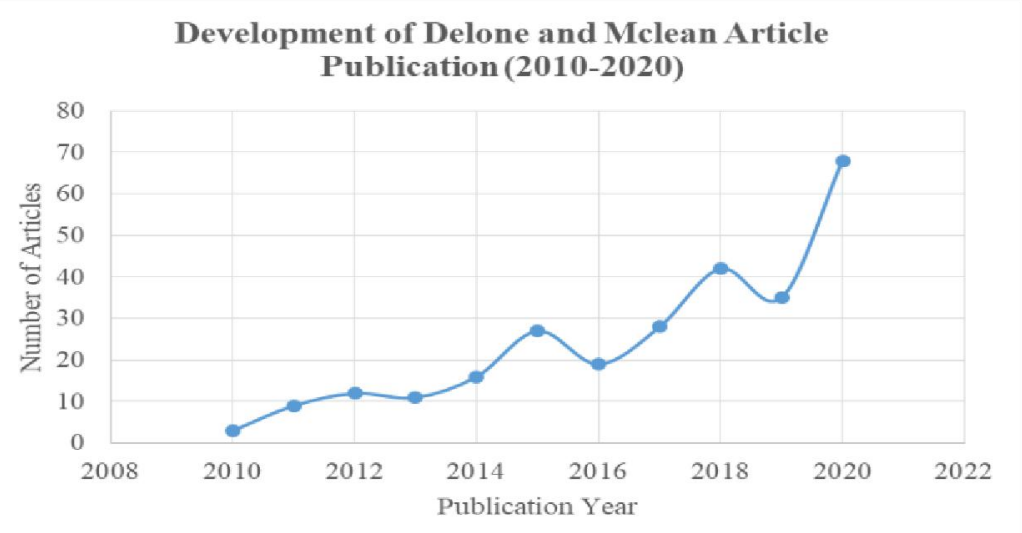

Fig 3. Graph of Delone and Mclean Publications (2010-2020)

Source: Data processed, 2021

The ten scientific articles with the highest number of citations on the topic of

\section{Delone and Mclean}

Table 2 shows that Nils Urbach and Benjamin Müller are the authors who have the highest number of citations, with 379 citations, with the article title The Updated Delone And Mclean Model Of Information Systems Success which was published in the journal Information Systems tTheory in 2012. Next for scientific articles which are 
ranked 2 to 10, which were published between 2010-2020 in full can be seen in table 2 below.

Table 2. Ten Articles With Most Cites

\begin{tabular}{|c|c|c|c|c|c|}
\hline $\begin{array}{l}\text { Cite } \\
\text { s }\end{array}$ & Author & Title & $\begin{array}{l}\text { Publication } \\
\text { Year }\end{array}$ & Publication & Publisher \\
\hline 379 & $\begin{array}{l}\text { Nils Urbach, } \\
\text { Benjamin } \\
\text { Müller } \\
{[11]}\end{array}$ & $\begin{array}{l}\text { The Updated Delone } \\
\text { And Mclean Model Of } \\
\text { Information Systems } \\
\text { Success }\end{array}$ & 2012 & $\begin{array}{l}\text { Information } \\
\text { systems theory }\end{array}$ & Springer \\
\hline 368 & $\begin{array}{l}\text { Meng-Hsiang } \\
\text { Hsu, Chun- } \\
\text { Ming Chang, } \\
\text { Kuo-Kuang } \\
\text { Chu, Yi-Jung } \\
\text { Lee } \\
\text { [12] }\end{array}$ & $\begin{array}{l}\text { Determinants Of } \\
\text { Repurchase Intention } \\
\text { In Online Group- } \\
\text { Buying: The } \\
\text { Perspectives Of Delone } \\
\text { \& Mclean IS Success } \\
\text { Model And Trust }\end{array}$ & 2014 & $\begin{array}{l}\text { Computers in } \\
\text { Human } \\
\text { Behavior }\end{array}$ & Elsevier \\
\hline 256 & $\begin{array}{l}\text { Carlos Tam, } \\
\text { Tiago Oliveira } \\
{[13]}\end{array}$ & $\begin{array}{l}\text { Understanding The } \\
\text { Impact Of M-Banking } \\
\text { On Individual } \\
\text { Performance: Delone } \\
\text { \& Mclean And TTF } \\
\text { Perspective }\end{array}$ & 2016 & $\begin{array}{l}\text { Computers in } \\
\text { Human } \\
\text { Behavior }\end{array}$ & Elsevier \\
\hline 202 & $\begin{array}{l}\text { Claus Bossen, } \\
\text { Lotte Groth } \\
\text { Jensen, } \\
\text { Flemming Witt } \\
\text { Udsen } \\
{[14]}\end{array}$ & $\begin{array}{l}\text { Evaluation Of A } \\
\text { Comprehensive EHR } \\
\text { Based On The Delone } \\
\text { And Mclean Model For } \\
\text { IS Success: Approach, } \\
\text { Results, And Success } \\
\text { Factors }\end{array}$ & 2013 & $\begin{array}{l}\text { International } \\
\text { Journal of } \\
\text { Medical } \\
\text { Informatics }\end{array}$ & Elsevier \\
\hline 154 & $\begin{array}{l}\text { Adnan } \\
\text { H.Aldholay, } \\
\text { Osam aIsaac, } \\
\text { Zaini } \\
\text { Abdullaha, } \\
\text { T.Ramayah } \\
\text { [15] }\end{array}$ & $\begin{array}{l}\text { The Role Of } \\
\text { Transformational } \\
\text { Leadership As A } \\
\text { Mediating Variable In } \\
\text { Delone And Mclean } \\
\text { Information System } \\
\text { Success Model: The } \\
\text { Context Of Online } \\
\text { Learning Usage In } \\
\text { Yemen }\end{array}$ & 2018 & $\begin{array}{l}\text { Telematics } \\
\text { and } \\
\text { Informatics }\end{array}$ & Elsevier \\
\hline 150 & $\begin{array}{l}\text { Carlos Tam, } \\
\text { Tiago Oliveira } \\
{[16]}\end{array}$ & $\begin{array}{l}\text { Understanding Mobile } \\
\text { Banking Individual } \\
\text { Performance: The } \\
\text { Delone \& Mclean } \\
\text { Model And The } \\
\text { Moderating Effects Of } \\
\text { Individual Culture }\end{array}$ & 2017 & $\begin{array}{l}\text { Internet } \\
\text { Research }\end{array}$ & $\begin{array}{l}\text { emerald.co } \\
\mathrm{m}\end{array}$ \\
\hline 141 & $\begin{array}{l}\text { Adebowale Ojo } \\
{[17]}\end{array}$ & $\begin{array}{l}\text { Validation Of The } \\
\text { Delone And Mclean } \\
\text { Information Systems } \\
\text { Success Model }\end{array}$ & 2017 & $\begin{array}{l}\text { Healthcare } \\
\text { informatics } \\
\text { research }\end{array}$ & $\begin{array}{l}\text { synapse. } \\
\text { koreamed. } \\
\text { org }\end{array}$ \\
\hline
\end{tabular}




\begin{tabular}{|c|c|c|c|c|c|}
\hline $\begin{array}{l}\text { Cite } \\
\text { s }\end{array}$ & Author & Title & $\begin{array}{l}\text { Publication } \\
\text { Year }\end{array}$ & Publication & Publisher \\
\hline 95 & $\begin{array}{l}\text { Ahmed } \\
\text { Ibrahim } \\
\text { Alzahrani, } \\
\text { Imran } \\
\text { Mahmud, T. } \\
\text { Ramayah, } \\
\text { Osama } \\
\text { Alfarraj, } \\
\text { Nasser } \\
\text { Alalwan } \\
\text { [18] }\end{array}$ & $\begin{array}{l}\text { Modelling Digital } \\
\text { Library Success Using } \\
\text { The Delone And } \\
\text { Mclean Information } \\
\text { System Success Model }\end{array}$ & 2019 & $\begin{array}{l}\text { Journal of } \\
\text { Librarianship } \\
\text { and } \\
\text { Information } \\
\text { Science }\end{array}$ & $\begin{array}{l}\text { journals. } \\
\text { sagepub.co } \\
\mathrm{m}\end{array}$ \\
\hline 93 & $\begin{array}{l}\text { Siti Mardiana, } \\
\text { Jann Hidajat } \\
\text { Tjakraatmadja, } \\
\text { Atik } \\
\text { Aprianingsih } \\
{[19]}\end{array}$ & $\begin{array}{l}\text { Delone-Mclean } \\
\text { Information System } \\
\text { Success Model } \\
\text { Revisited: The } \\
\text { Separation Of Intention } \\
\text { To Use-Use And The } \\
\text { Integration Of } \\
\text { Technology } \\
\text { Acceptance Models }\end{array}$ & 2015 & $\begin{array}{l}\text { International } \\
\text { Journal of } \\
\text { Economics } \\
\text { and Financial }\end{array}$ & $\begin{array}{l}\text { researchgat } \\
\text { e.net }\end{array}$ \\
\hline 88 & $\begin{array}{l}\text { Mutaz M. Al- } \\
\text { Debei, Dima } \\
\text { Jalal, Enas Al- } \\
\text { Lozi } \\
{[20]}\end{array}$ & $\begin{array}{l}\text { Measuring Web Portals } \\
\text { Success: A } \\
\text { Respecification And } \\
\text { Validation Of The } \\
\text { Delone And Mclean } \\
\text { Information Systems } \\
\text { Success Model }\end{array}$ & 2013 & $\begin{array}{l}\text { International } \\
\text { Journal of } \\
\text { Business } \\
\text { Information } \\
\text { Systems }\end{array}$ & $\begin{array}{l}\text { Inderscien } \\
\text { ceonline } \\
\text {.com }\end{array}$ \\
\hline
\end{tabular}

Source: Data processed, 2021

\section{Delone and Mclean Model Publication Progress Map 2010-2020}

The publication development map using the Delone and Mclean model in Figure 2 shows that there are 5 clusters, namely: (1) red cluster 1 with 15 items: acceptance, adoption, analysist, delone \& mclean model, d\&m, factor, framework, implementation, integration, intention, performance, perspective, technology, trust, use; d\&m, delone \& mclean, framework, influence, information, intention, clean method, performance, perspective, quality, satisfaction, service, trust, usage; (2) green cluster 2 with 11 items: experience, influence, information, clean information system success model, net benefit, quality, relationship, satisfaction, service, system, usage; (3) blue cluster 3 with 10 items: adaptation, effectiveness, evaluation, extention, information system, is success model, respecification, success model, user, validation; and (4) yellow cluster 4 with 6 items: individual impact, information quality, problem, service quality, system quality, user satisfaction. 


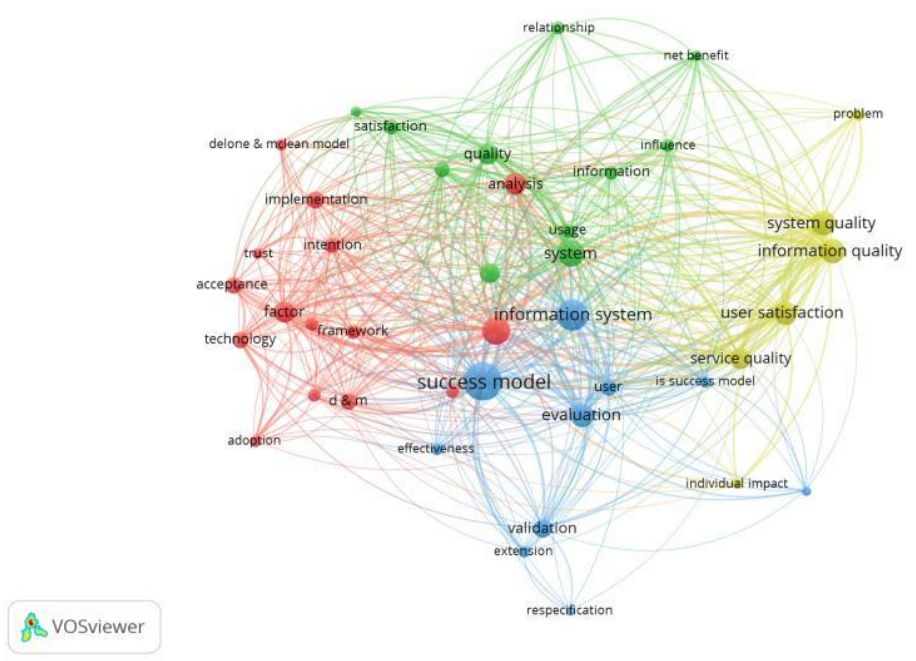

Fig 4. Development Map of Delone and Mclean Model Publications 2010-2020

Source: Data processed, 2021 (VOSViewer)

\section{CONCLUSION}

Based on the results and discussion, it can be concluded that the growth trend of the Delone and Mclean model significantly in 2010-2020 in the Google Scholar database continues to increase with the highest number of publications, namely in 2020 as many as 68 articles or $25 \%$. The authors who have the highest number of citations in the 2010-2020 period are Nils Urbach and Benjamin Müller (2012) with 379 citations with the article title The Updated Delone And Mclean Model Of Information Systems Success. Furthermore, the development map based on co-occurrence and keywords from the analysis results in VOSViewer is divided into 4 clusters.

\section{ACKNOWLEDGMENTS}

Thanks to all parties involved so that this research can be completed, and thanks also to STMIK Rosma who has facilitated the author during the preparation of this article.

\section{REFERENCES}

[1] F. Sapty Rahayu, R. Apriliyanto, and Y. Sigit Purnomo Wuryo Putro, "Analisis Kesuksesan Sistem Informasi Kemahasiswaan (SIKMA) dengan Pendekatan Model DeLone dan McLean," Indones. J. Inf. Syst., vol. 1, no. 1, pp. 34-46, 2018, doi: 10.24002/ijis.v1i1.1704.

[2] S. Hidayatullah, U. Khouroh, I. Windhyastiti, R. G. Patalo, and A. Waris, "Implementasi Model Kesuksesan Sistem Informasi DeLone And McLean Terhadap Sistem Pembelajaran Berbasis Aplikasi Zoom Di Saat Pandemi Covid-19," J. Teknol. dan Manaj. Inform., vol. 6, no. 1, pp. 44-52, 2020, doi: 10.26905/jtmi.v6i1.4165.

[3] D. Mardiana, G. Testiana, and M. Kadafi, "Penerapan Model Delone dan Mclean 
Pengukuran Kesuksesan Simak Online UIN Raden Fatah Palembang," Penerapan Model Delone dan Mclean Pengukuran Kesuksesan Simak Online UIN Raden Fatah Palembang Dwi, vol. 3584, pp. 47-56, 2017.

[4] T. P. KPPRI, "Panduan Pembuatan Profil Google Scholar," Universitas Indonesia, 2017. [Online]. Available:

https://research.ui.ac.id/research/wp-content/uploads/2017/02/Panduan-MembuatProfil-Google-Scholar.pdf.

[5] A. M. Albantani, "Profil Google Scholar Dosen Uin Syarif Hidayatullah Jakarta Berbasis Webometrics," Perspekt. Ilmu Pendidik., vol. 30, no. 1, p. 47, 2016, doi: 10.21009/pip.301.7.

[6] Tupan, R. N. Rahayu, R. Rachmawati, and E. S. R. Rahayu, "ANALISIS BIBLIOMETRIK PERKEMBANGAN PENELITIAN BIDANG ILMU INSTRUMENTASI," BACA J. Dokumentasi dan Inf., vol. 39, no. 2, pp. 135-149, 2018.

[7] F. Effendy, V. Gaffar, R. Hurriyati, and H. Hendrayati, "Penggunaan Pembayaran Seluler Dengan Vosviewer," J. Interkom, vol. 16, no. 1, pp. 10-17, 2021.

[8] P. Mongeon and A. Paul-Hus, "The journal coverage of Web of Science and Scopus: a Comparative Analysis," Scientometrics, vol. 106, no. 1, pp. 213-228, 2016, doi: 10.1007/s11192-015-1765-5.

[9] L. Hakim, "Analisis Bibliometrik penelitian inkubator bisnis pada publikasi ilmiah terindeks Scopus,” Procur. J. IIm. Manaj., vol. 8, no. 2, pp. 176-189, 2020.

[10] Tupan, "Pemetaan Bibliometrik dengan Vosviewer Terhadap Perkembangan Hasil Penelitian Bidang Pertanian Di Indonesia," Visi Pustaka, vol. 18, no. 3, pp. 217-230, 2016.

[11] B. M. Nils Urbach, "The Updated Delone And Mclean Model Of Information Systems Success," Inf. Syst. Theory, vol. 28, no. May, p. 461, 2012, doi: 10.1007/978-1-44196108-2.

[12] M.-H. Hsu, C.-M. Chang, K.-K. Chu, and Y.-J. Lee, "Determinants of repurchase intention in online group-buying: The perspectives of DeLone \& McLean IS success model and trust," Comput. Human Behav., vol. 36, pp. 234-245 Contents, 2014.

[13] C. Tam and T. Oliveira, "Understanding the impact of m-banking on individual performance: DeLone \& McLean and TTF perspective," Comput. Human Behav., vol. 61, p. 233e244 Contents, 2016.

[14] C. Bossen, L. G. Jensen, and F. W. Udsen, "Evaluation of a comprehensive EHR based on the DeLone and McLean model for IS success: approach, results, and success factors," Int. J. Med. Inform., vol. 85, pp. 940-953, 2013.

[15] A. H. Aldholay, O. Isaac, Z. Abdullah, and T. Ramayah, "The role of transformational leadership as a mediating variable in DeLone and McLean information system success model: The context of online learning usage in Yemen," Telemat. Informatics, vol. 35, no. 5, pp. 1421-1437, 2018, doi: 10.1016/j.tele.2018.03.012.

[16] C. Tam and T. Oliveira, "Understanding mobile banking individual performance: The DeLone \& McLean model and the moderating effects of individual culture," Internet Res., vol. 27, no. 3, pp. 538-562, 2017, doi: 10.1108/IntR-05-2016-0117.

[17] A. Ojo, "Validation of the DeLone and McLean information systems success model," Healthc. Inform. Res., vol. 23, no. 1, pp. 60-66, 2017. 
[18] A. I. Alzahrani, I. Mahmud, T. Ramayah, Osama Alfarraj, and N. Alalwan, "Modelling digital library success using the DeLone and McLean information system success model," J. Librariansh. Inf. Sci., pp. 1-16, 2017, doi: 10.1177/0961000617726123.

[19] S. Mardiana, J. H. Tjakraatmadja, and A. Aprianingsih, "DeLone-Mclean information system success model revisited: The separation of intention to Use - Use and the integration of technology acceptance models," Int. J. Econ. Financ. Issues, vol. 5, pp. 172-182, 2015.

[20] M. M. Al-Debei, D. Jalal, and E. Al-Lozi, Measuring web portals success: A respecification and validation of the DeLone and McLean information systems success model, vol. 14, no. 1. 2013. 